\title{
PENGARUH GENIUS LEARNING STRATEGY TERHADAP KEMAMPUAN BERPIKIR TINGKAT TINGGI PADA MATERI SISTEM PERNAPASAN MANUSIA
}

\author{
Gloria Sirait ${ }^{1}$, Ely Djulia ${ }^{2}$, Saria Sinaga ${ }^{3}$ \\ 1,2Program Studi Pendidikan Biologi, FMIPA, Universitas Negeri Medan, Medan \\ Jl. Willem Iskandar Psr. V Medan Estate, Medan, Indonesia, 20221 \\ ${ }^{3}$ Guru IPA SMP Negeri 1 Tebing Tinggi, Jl. Dr. Sutomo No.15, Rambung, Kec. Tebing Tinggi Kota, Kota Tebing Tinggi, \\ Sumatera Utara 20633 \\ *Korespondensi Author: gloriasirait23@gmail.com
}

\section{INFO ARTIKEL}

Histori Artikel

Received 15 November 2019

Revised 29 Januari 2019

Accepted 29 Januari 2020

Published 30 Januari 2020

Keywords:

Genius Learning strategy, kemampuan berpikir tingkat tinggi, sistem pernapasan manusia

\begin{abstract}
ABSTRAK
Telah dilakukan penelitian tentang pengaruh genius learning strategy terhadap kemampuan berpikir tingkat tinggi pada materi sistem pernapasan manusia di siswa kelas VIII SMP Negeri 1 Tebing Tinggi untuk Tahun Ajaran 2018/2019. Penelitian ini sendiri menggunakan metode quaksi experimental (quasi eksperimen). Penelitian dengan quasi eksperimen ini bertujuan untuk mengetahui pengaruh genius learning strategy terhadap kemampuan berfikir tingkat tinggi siswa kelas VIII SMP Negeri 1 Tebing Tinggi pada materi Sistem Pernapasan Manusia T.P 2018/2019 serta mengetahui hubungan antara genius learning strategy dengan kemampuan berpikir tingkat tinggi. Jenis Sampel diambil dengan teknik Purposive Sampling yaitu siswa/i kelas VIII-7 dan VIII-8 SMP Negeri 1 Tebing Tinggi yang berjumlah 82 orang. Instrumen yang digunakan pada penelitian ini berupa tes kemampuan berpikir tingkat tinggi setiap siswa. Adapun Teknik analisis data yang digunakan dalam penelitian ini adalah uji-t. Hasil penelitian dapat disimpulkan bahwa terdapat pengaruh yang signifikangenius learning strategy terhadap kemampuan berpikir tingkat tinggi dengan nilai sig 0,000<0,05.
\end{abstract}

\begin{abstract}
ABSTRAK
This quasi-experimental study aims to determine the effect of genius learning strategy on the high-level thinking ability of Grade VIII students of SMP Negeri 1 Tebing Tinggi on material Human Respiratory System T.P 2018/2019 and to find out the relationship between genius learning strategy and the ability to think at a higher level. Samples were taken by purposive sampling technique, namely students of class VIII-7 and VIII-8 SMP Negeri 1 Tebing Tinggi, amounting to 82 people. The instruments used were tests of high-level thinking ability of each student. The data analysis technique used is the t-test. The results of the study concluded that there was a significant influence of genius learning strategy on higher order thinking skills with a sig value of $0,000<0.05$.
\end{abstract}

Copyright @ 2019 Universitas Negeri Medan. Artikel Open Access dibawah lisensi CCBY-4.0 (https://creativecommons.org/licenses/by/4.0)

\section{How To Cite:}

Sirait, G., Djulia, E., \& Sinaga. S. (2019). Pengaruh Genius Learning Strategy Terhadap Kemampuan Berpikir Tingkat Tinggi Pada Materi Sistem Pernapasan Manusia. Jurnal Pelita Pendidikan, 7(4), 191-196. 


\section{PENDAHULUAN}

Tujuan kurikulum 2013 pada jenjang SMP/MTS adalah mempersiapkan manusia Indonesia agar memiliki kemampuan hidup sebagai pribadi dan warga negara yang beriman, produktif, kreatif,inovatif dan efektif serta mampu berkontribusi pada kehidupan bermasyarakat, berbangsa dan peradaban dunia. Tujuan kurikulum tersebut dapat dicapai dengan adanya proses pembelajaran yang efektif. Salah satu masalah yang dihadapi dunia pendidikan saat ini adalah lemahnya proses pembelajaran. Proses pembelajaran pada umumnya dilaksanakan oleh guru lebih banyak menekankan pada aspek pengetahuan dan pemahaman sedangkan aspek aplikasi, analisis, sintesis, bahkan evaluasi hanya sebagian kecil dari pembelajaran yang dilakukan (Purba, 2011). Pembelajaran masih bersifat Teacher oriented dan siswa kurang diberi kesempatan untuk mengembangkan kemampuan berpikir tingkat tinggi.

Pola Pembelajaran SMP sudah mulai menekankan bagaimana siswa tersebut dapat menganalisis, mensintesis dan mengevalusi pembelajaran melalui soal atau yang disebut dengan berfikir tingkat tinggi diantaranya yaitu melibatkan kemampuan analisis, evaluasi, dan mencipta. (Putri et al, 2015). Kemampuan berfikir tingkat tinggilah yang dinilai masih belum maksimal karena di beberapa instrument evaluasi belajar (soal) banyak dominan menggunakan kemampuan berfikir tingkat rendah (Naputri et al, 2016). Strategi pembelajaran dapat digunakan sebagai sarana guru melaksanakan pembelajaran dan mencapai tujuan pembelajaran (Padang dan Djulia, 2016). Strategi pembelajaran merupakan cara-cara yang akan dipilih dan digunakan oleh seorang pengajar untuk menyampaikan materi pembelajaran, sehingga akan memudahkan peserta didik mencapai tujuan yang dikuasai di akhir kegiatan belajar.

Strategi Pembelajaran Jenius (Genius Learning Strategy) merupakan pengembangan dari metode Accelerated Learning oleh Dr.Georgi Lozanov. Genius Learning Strategy ini adalah suatu sistem yang terancang dengan satu jalinan yang sangat efisien yang meliputi diri anak didik, guru, proses pembelajaran dan lingkungan pembelajaran (Dewi, 2010) . Genius learning strategy menawarkan pembelajarann yang memotivasi potensi otak, dan kemampuan belajar siswa pada level yang lebih tinggi sehingga apa yang telah dipelajarinya dapat diterapkan dalam kehidupan sehari-hari (Gunawan, 2012). Pengembangan Genius learning telah dilakukan dengan mempertimbangkan kondisi masyarakat Indonesia secara umum, kebudayaan bangsa, kondisi sosial ekonomi, sistem pendidikan nasional, dan tujuan pendidikan Indonesia.

Genius learning startegy atau lebih tepat disebut sebagai Holistic Learning adalah istilah yang digunakan untuk menjelaskan suatu rangkaian pendekatan praktis dalam upaya meningkatkan hasil pembelajaran. Upaya peningkatan ini dicapai dengan menggunakan pengetahuan yang berasal dari berbagai displin ilmu seperti pengetahuan tentang cara kerja otak, cara kerja memory, neurolinguistic programming, motivasi, konsep diri, kepribadian, emosi, perasaan, pikiran, metakognisi, gaya belajar, multiple intellegence atau kecerdasan jamak, teknik memori, teknik membaca, teknik mencatat, dan tenik belajar lainnya (Gunawan, 2012).

Pembelajaran menggunakan delapan lingkaran sukses genius learning yaitu, suasana kondusif, hubungkan, gambaran besar, tetapkan tujuan, pemasukan informasi, aktivasi, demonstrasi, ulangi dan jangkarakan, dapat membantu siswa untuk berpikir kritis. Kegiatan pembelajaran yang didesain sesuai dengan kebutuhan siswa, kemudian siswa sebagai subyek mengakibatkan peran aktif siswa dalam memperoleh pengetahuan secara mandiri. Kegiatan dalam genius learning mendukung pengembangan keterampilan siswa dalam menyelesaikan masalah, menganalisis masalah dengan pengetahuan yang telah diketahui sebelumnya dan yang diperoleh saat pembelajaran berlangsung yang disebut dengan kemampuan berpikir tingkat tinggi (Andriyani et al, 2015).

Peneliti melakukan tindakan terhadap permasalahan hasil belajar siswa yang masih dibawah nilai kriteria ketuntasan minimal yaitu dengan memberikan Genius Learning Strategy pada materi sistem pernapasan manusia di kelas eksperimen (VIII-8).

\section{METODE PENELITIAN}

Populasi penelitian adalah seluruh siswa kelas VIII SMP Negeri 1 Tebing Tinggi yang terdiri dari 10 
kelas yang berjumlah 410. Sampel diambil secara Purposive Sampling berdasarkan pertimbangan peneliti untuk melihat pengaruh genius learning strategy terhadap kemampuan berpikir tingkat tinggi siswa. Dan didapatkan 2 kelas yaitu kelas VIII7 berjumlah 41 siswa sebagai kontrol kelas dan kelas VIII-8 berjumlah 41 siswa sebagai kelas Eksperimen.

Variabel-variabel yang digunakan dalam penelitian ini dibedakan atas dua, yaitu variabel bebas dalam penelitian ini adalah Genius Learning Strategy. Sedangkan variabel terikat dalam penelitian ini adalah kemampuan berfikir tingkat tinggi dan konsep diri siswa. Jenis penelitian yang digunakan dalam penelitian ini adalah jenis penelitian quasi eksperimen, yaitu penelitin yang dimaksudkan untuk mengetahui ada tidaknya pengaruh dari perlakuan yang diberikan kepada siswa sebagai subjek penelitian.

Berdasarkan tujuan penelitian yaitu untuk mengetahui pengaruh Genius Learning Strategy terhadap kemampuan berfikir tingkat tinggi pada materi sistem pernapasan manusia kelas VIII SMP Negeri 1 Tebing Tinggi tahun pembelajaran 2018/2019, maka peneliti menggunakan rancangan pretest- postest control group design yang bertujuan untuk mengetahui hasil pembelajaran siswa dengan sebelum dan sesudah diberi perlakuan.Instrumen Penelitian ini adalah menggunakan tes hasil belajar tingkat tinggi siswa disusun dalam bentuk pilihan dengan 5 option (a,b,c,d dan e). Tes disusun berdasarkan materi yang diajarkan kepada siswa. Pembelajaran menggunakan delapan lingkaran sukses genius learning yaitu, suasana kondusif, hubungkan, gambaran besar, tetapkan tujuan, pemasukan informasi, aktivasi, demonstrasi, ulangi dan jangkarakan, dapat membantu siswa untuk berpikir kritis. Kegiatan pembelajaran yang didesain sesuai dengan kebutuhan siswa, kemudian siswa sebagai subyek pembelajaran mengakibatkan peran aktif siswa dalam memperoleh pengetahuan secara mandiri. Kegiatan dalam genius learning mendukung pengembangan keterampilan siswa dalam menyelesaikan masalah, menganalisis masalah dengan pengetahuan yang telah diketahui sebelumnya dan yang diperoleh saat pembelajaran berlangsung (Andriyani et al, 2015).

\section{HASIL DAN PEMBAHASAN}

Data Nilai Pretes

Pre-tes dilakukan untuk melihat kemampuan awal siswa mengenai materi tersebut. Nilai pre-tes untuk kedua kelas tergolong sangat rendah dengan rata-rata nilai pretes pada kelas Konvensional adalah 36,98 dan standar deviasinya adalah 10,81, sementara rata-rata nilai pretes pada kelas GLS adalah 33,22 dan standar deviasinya adalah 10,94.

\section{Data Nilai Postes}

Postest dilakukan untuk melihat kemampuan akhir siswa mengenai materi tersebut. Nilai postest siswa untuk kedua kelas adalah ratarata nilai postes pada kelas kontrol adalah 43,98 dan standar deviasinya adalah 11,64, sementara rata-rata nilai postes pada kelas GLS adalah 53,76 dan standar deviasiny adalah 14,48. Dari hasil tersebut diperoleh bahwa nilai rata-rata kelas GLS lebih tinggi daripada kelas kontrol.

\section{Uji Prasyarat}

Berdasarkan hasil uji Normalitas data dengan menggunakan uji Kolmogorov-smirnov test, diketahui bahwa data Kemampuan Bepikir Tingkat Tinggi diperoleh nilai sig 0,008 $>0,05$ yang berarti data berdistribusi Normal.

Berdasarkan hasil uji homogentitas data dengan menggunakan uji Levene's test, diketahui bahwa data Pretes Kemampuan Berpikir Tingkat Tinggi siswa diperoleh nilai sig 0,101 > 0,05 yang berarti data memiliki varians yang sama (Homogen).

\section{Pengujian Hipotesis}

Berdasarkan perhitungan yang dilakukan mengenai uji hipotesis atau uji $t$ didapatkan hasil sebagai berikut. 
Tabel 1. Uji t data pretes-postest kelas Kontrol dan GLS

\begin{tabular}{l|c|c|c|c|c|c|c}
\hline \multicolumn{1}{c|}{ Kelas } & Rata-rata & $\mathbf{N}$ & SD & Sig & t hitung & t tabel & Keterangan \\
\hline Kontrol & 43,98 & 41 & 11,64 & 0,001 & -3.631 & 2,021 & Ha Diterima \\
GLS & 53,76 & 41 & 14,48 & 0,000 & -11.299 & & \\
\hline
\end{tabular}

Penelitian ini mengambil 2 kelas sebagai sampel yaitu kelas VIII-7 dengan pembelajaran konvensional dan kelas VIII-8 dengan genius learning strategy (GLS). Sebelum memberikan perlakuan yang berbeda-beda pada kedua kelas eksperimen, peneliti terlebih dahulu memberikan pre-tes untuk melihat kemampuan dasar siswa mengenai materi pokok sistem pernapasan manusia. Setelah pembelajaran selesai diberikan postes pada masing-masing kelas.

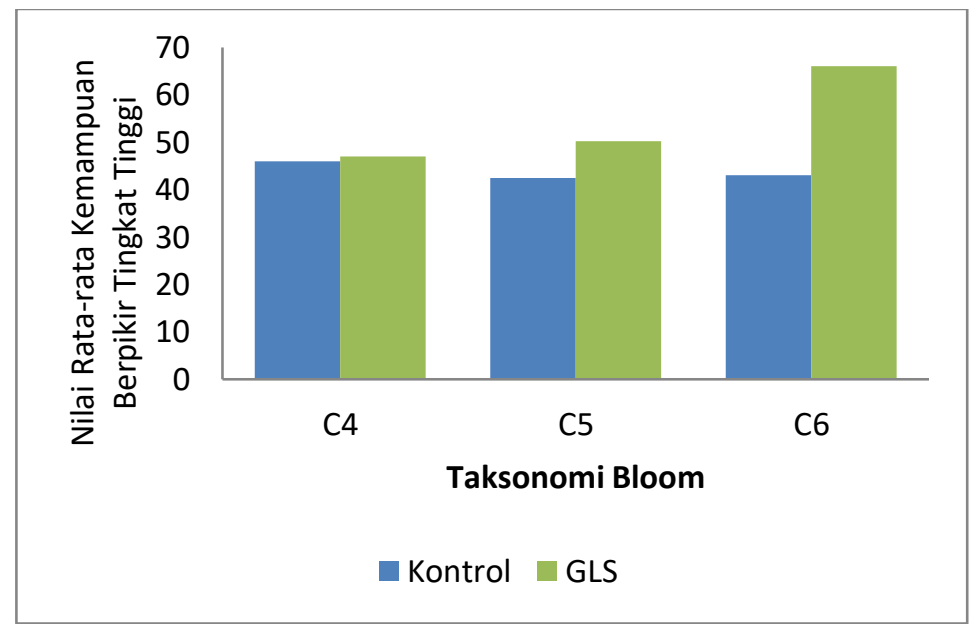

Gambar 1. Kemampuan Berpikir Tingkat Tinggi Siswa Kelas Kontrol (VIII-7) dan Kelas Genius Learning Strategy (VIII-8) berdasarkan Taksonomi Bloom pada Materi Sistem Pernapasan Manusia di SMP Negeri 1 Tebing Tinggi.

Dari gambar di atas diperoleh nilai rata-rata hasil belajar siswa berdasarkan Taksonomi Bloom Kelas Genius Learning Strategy lebih unggul dari pada kelas Kontrol dimana pada soal C4 dengan nilai rata-rata 47 dan standar deviasi 17,23, C5 sebesar 50,24 dengan nilai standar deviasi 15,24 dan $\mathrm{C} 6$ sebesar 65,85 dengan nilai standar deviasi 23, sedangkan pada kelas Konvensional dimana pada soal $C 4$ sebesar 46 dengan nilai standar deviasi 15,24, C5 sebesar 41,71 dengan nilai standar deviasi 16,55 dan 66 sebesar 43,09 dengan standar deviasi 19. Dari gambar 4.2 diperoleh nilai rata-rata kemampuan berpikir tingkat tinggi siswa berdasarkan indikator pembelajaran menunjukkan kelas GLS lebih unggul daripada kelas Kontrol untuk keempat indikator pembelajaran pada materi sistem pernapasan manusia. Dimana untuk indikator 1 kelas kontrol memperoleh 55,28 sedangkan kelas GLS 68,7. Pada indikator 2 kelas kontrol memperoleh 43,09 sedangkan kelas GLS 50,2 . Pada indikator 3 kelas kontrol memperoleh 59,35 sedangkan kelas GLS 62,6. Pada indikator 4 kelas kontrol memperoleh 32,52 sedangkan kelas GLS 45,53.

Hasil penelitian ini memperkuat teori Pemprosesan informasi menurut Robert Gagne (1988), yaitu teori kognitif tentang belajar yang menjelaskan pemprosesan, penyimpanan dan pemanggilan kembali pengetahuan dari otak. Penelitian sebelumnya yang mendukung penelitian ini yaitu penelitian yang dilakukan oleh Andriayani, Parmin dan Akhlis (2015) yang berjudul Penerapan Genius Learning untuk mengukur keterampilan berpikir kritis siswa pada materi ekosistem. Hal ini terbukti dari hasil analisis korelasi product moment (rxy) pengaruh genius learning terhadap keterampilan berpikir kritis siswa adalah 0,85 (kategori sangat kuat). 


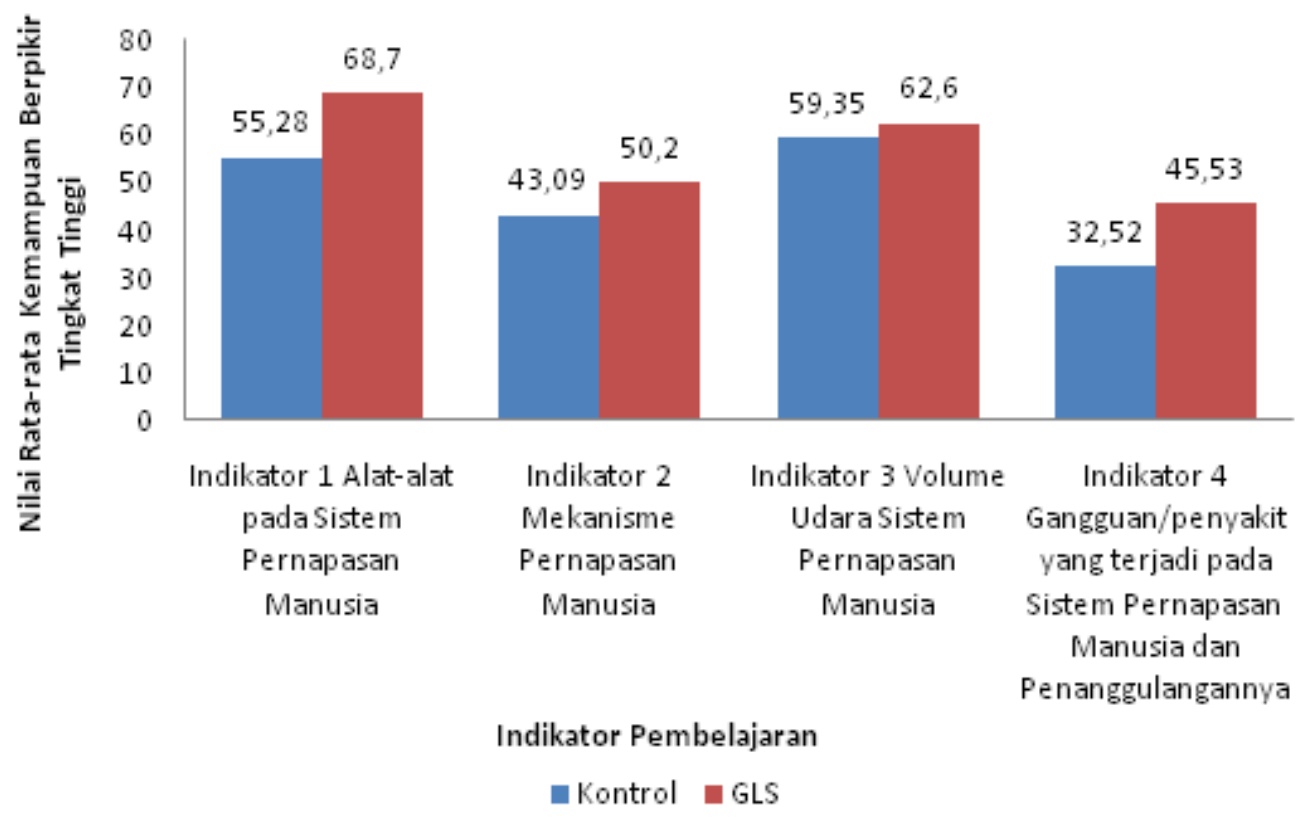

Gambar 2. Kemampuan Berpikir Tingkat Tinggi siswa kelas kontrol (VIII-7) dan kelas GLS (VIII-8) berdasarkan Indikator Pembelajaran pada Materi Sistem Pernapasan Manusia di SMP Negeri 1 Tebing Tinggi

\section{Pengaruh Genius Learning Strategy Terhadap Kemampuan Berpikir Tingkat Tinggi}

Hasil penelitian menunjukkan bahwa ada pengaruh yang signifikan genius learning strategy terhadap kemampuan berfikir tingkat tinggi siswa kelas VIII SMP Negeri 1 Tebing Tinggi pada materi Sistem Pernapasan Manusia T.P 2018/2019. Hal ini dibuktikan denganhasil uji-t yang dilakukan pada nilai pretes dan postes kedua kelas. Dimana, kelas konvensional memiliki nilai signifikansi 0,001 <0,05 dan kelas GLS memiliki nilai signifikansi 0,000 $<0,05$ dengan nilai Ttabel < Thitung, $2,021<-11,299$. maka hipotesis alternatif (Ha) diterima. Dalam hal ini dapat disimpulkan bahwa ada pengaruh genius learning strategy terhadap kemampuan berpikir tingkat tinggi siswa. Yang artinya semakin sering genius learning strategy digunakan dalam proses pembelajaran maka dapat meningkatkan kemampuan berpikir tingkat tinggi siswa.

\section{KESIMPULAN}

Berdasarkan hasil penelitian yang diperoleh dari hasil analisa data dan pengujian hipotesis maka dapat di disimpulkan, bahwa terdapat pengaruh yang signifikan dengan menggunakan Genius Learning Strategy terhadap Kemampuan Berpikir Tingkat Tinggi Siswa pada Materi Sistem Pernapasan Manusia kelas VIII SMP Negeri 1 Tebing Tinggi T.P 2018/2019.

\section{DAFTAR PUSTAKA}

Andriyani, R., Parmin., Akhlis, I, (2015), Penerapan Genius Learning Untuk Mengukur Keterampilan Berpikir Kritis Siswa Pada Materi Ekosistem.Jurnal Pendidikan IPA Unnes, 4 (3): 1005-1013.

Dewi, E, (2010), Pengaruh Genius Learning Strategy Terhadap Hasil Belajar Biologi Siswa Pada Materi Pokok Sistem Reproduksi Manusia Kelas XI IPA SMA Negeri 8 Medan Tahun Pembelajaran 2009/2010., Skripsi, Unimed, Medan.

Gunawan, W, A., (2012), Genius Learning Strategy Petunjuk Praktis untuk Menerapkan Accelerated Learning, PT.Gramedia Pustaka Utama, Jakarta.

Naputri, Ridho, F., Syarifuddin., Djulia, E., (2016), Pengaruh Strategi Pembelajaran Berbasis Masalah dan Minat Belajar Terhadap Kemampuan Berpikir Kritis dan Hasil Belajar Siswa Pada Materi Sistem Pencernaan Makanan Manusia Di MAS Amaliyah 
Sunggal, Jurnal Pendidikan Biologi, 5(2): 119-

130.

Padang, Sabrina, J., Djulia, E., (2016), Perbedaan Hasil Belajar Siswa Melalui Penerapan Metode Two Stay Two Stray Dengan Think Pair Share Tentang Sistem Peredaran Darah Pada ManusiaDi Kelas VIII SMP Negeri 2 Pancur atu, Jurnal Pendidikan Biologi, T.P 2014/2015, 4(1): 1-6.

Purba, M. (2011), Pengaruh Frekuensi Tes Dalam Tatanan Strategi Pembelajarn Kuantum Terhadap Hasil Belajar Kognitif Tingkat Tinggi Pada Siswa SMA Negeri 1 Girsang Sipanganbolon., Tesis, PPS, Unimed. Medan.

Putri, A, Nurwidodo. N, Pantiwati, Y.,(2015), Perbedaan Model Pembelajaran Open Inquiry Dan Guided Inquiry Berdaasarakan Kemandirian Belajar Dan Berfikir Tingkat Tinggi Pada Mata Pelajaran Biologi Kelas 11 Man Tempursari-Ngawi, Jurnal Pendidikan Biologi Indonesia, 1(1):27-34. 